\title{
Influence of Dredging and Dumping Zones on the Ecological Situation in the Kerch Strait
}

\author{
P. D. Lomakin \\ Marine Hydrophysical Institute of RAS, Sevastopol, Russian Federation \\ p_lomakin@mail.ru
}

\begin{abstract}
Introduction. In the present paper structural regularities of the total suspended matter (TSM) and dissolved organic matter (DOM) content fields and the dissolved oil products (OP) concentration in the dredging and dumping areas in the Kerch Strait and the adjacent regions are identified based on the oceanographic data of the expeditions of the Marine Hydrophysical Institute and the Southern Research Institute of Marine Fishery and Oceanography

Data and methods. The data of nine complex expeditions in the Kerch Strait in 1999-2013 were analyzed. The concentrations of all the substances under study were determined applying the optical methods. All the surveys were carried out in a probing mode using the Kondor optical probe.

Results. It is shown that sea dredging in the commercial port of Kerch was accompanied by significant increase of the total suspended matter content; its concentration was dozen times higher than that in the adjacent area. High content of the total suspended matter, characteristic for the port and the surrounding waters, contributes to accumulation and deposition of the anthropogenic dissolved organic matter, which concentration significantly exceeds the natural one. It is revealed that the dumping zones remain the sources of seawater environment pollution. The pronounced local maxima of the total suspended matter, dissolved organic matter and dissolved oil products concentrations were revealed in the bottom layer just in these zones: here they 1.5-3 times exceeded the natural standards of the considered characteristics.

Discussion and conclusion. Dredging is the most significant factor determining the high concentration of suspended matter of anthropogenic origin in the Kerch Strait. The soil removed during dredging has an extremely low compaction and abnormally high fluidity that promotes intensive erosion of the dumping zones and further spread of suspension in the ambient waters. Dredging and dumping zones are not only pockets of environmental hazards; they are also unfavorable for navigation.
\end{abstract}

Keywords: dredging, dumping zones, total suspended mater, dissolved organic mater, oil products, the Kerch Strait.

Acknowledgments: The study was carried within the framework of the state tasks on theme No. 0827- 2014-0011 "Study of The Regularities in Changes of the Marine Environment State Based on the Operational Observations and the Data of the System of Nowcast, Forecast and Reanalysis of the Marine Water Areas State" and theme No. 0827-2014-0010 "Complex Interdisciplinary Research of the Oceanological Processes Determine the Functioning and Evolution of the Ecosystems of the Black and Azov Seas, based on Modern Methods for Marine Environment State and Grid Technologies"

For citation: Lomakin, P.D., 2019. Influence of Dredging and Dumping Zones on the Ecological Situation in the Kerch Strait. Physical Oceanography, [e-journal] 26 (2), pp. 147-156. doi:10.22449/1573-160X-2019-2-147-156

DOI: $10.22449 / 1573-160 \mathrm{X}-2019-2-147-156$

(C) 2019, P. D. Lomakin

(C) 2019, Physical Oceanography 


\section{Introduction}

The 60 s and 80 s of the last century in the Kerch Strait were marked by the navigation and port activity intensification. Then the existing ports were modernized, new ports, shipyards, port points, cargo terminals were built. Appeared new shipping canals, the existing ones were deepened. Dredging works were massively carried out. Some dumping zones (specially designated areas intended for dumping of the soil, taken during the dredging) were organized.

Such a powerful anthropogenic press was accompanied by a negative response, manifested in various parameters of the aquatic environment state, which was actively studied in the 1970 s - 1990s as part of numerous governmental programs. The results of these studies, belonging mainly to such well-known specialists of the Soviet period, as E. N. Nevesky, V. A. Bryantsev, L. K. Sebah, S. P. Volovik, S. F. Rogov, V. V. Shishkin and V. P. Usenko, are summarized in [1].

One of directions of the research carried out at that time, dealing with the topics covered in this work, had been terminated by about the year of 2000. From the beginning of this century, operational probe optical observation methods were introduced into the practice of the Kerch Strait expedition by the Marine Hydrophysical Institute. They permitted to obtain information on elements that were not measured before and significantly expanded the empirical database on the aquatic environment state of this region.

The present paper is aimed to compile and analyze the new information obtained mainly after 2000, which complement the current views and reflect the peculiarities of the impact of dredging and dumping of land on the ecological situation in the Kerch Strait at the current stage.

Note that the issues of the dredging and dumping zone impact on the ecology of the coastal zone of oceans and seas are widely covered in modern literature [2-5].

\section{Initial Data and Research Methods}

The initial data for the analysis were the materials of 9 complex expeditions conducted by the Marine Hydrophysical Institute (MHI, Sevastopol) and the Southern Research Institute of Marine Fisheries and Oceanography (YugNIRO, Kerch) in the Kerch Strait in 1999-2013. Hydrographic survey data and new information related to dredging issues in the Kerch Strait and the accompanying environmental effects were also analyzed.

The fields of the elements of the aquatic environment that are not traditional for classical oceanography are considered, such as: the content of the total suspended (TSM) and dissolved organic (DOM) matters, as well as the concentration of oil products (OP) dissolved in water.

The TSM and DOM content was determined on the basis of optical methods [6, 7], implemented in the Kondor Optical Probing Complex (URL: http://ecodevice.com.ua/ecodevice-catalogue/multiturbidimeter-kondor). By means of this device, arrays of synchronous in situ measurements of the TSM and DOM content in a probing mode with a depth resolution of $0.1 \mathrm{~m}$ were accumulated and analyzed. Note that DOM characterizing anthropogenic pollution, including the bacterial one, is one of the best water quality indicators of coastal marine and oceanic areas $[8,9]$. 
Concentration of oil products dissolved in seawater was determined in water samples taken under laboratory conditions using the traditional fluorescence method (UV-fluorescence method) [10]. This value is presented in relative units (relative units) and shows the quantity of times the measured content of oil products exceeds the concentration in uncontaminated waters of the central Black Sea, which is taken as a unit.

Oil products dissolved in water is an important indicator of water pollution, which has not previously been measured in the Strait waters. The dissolved OP fraction is adsorbed on a suspension is quite stable and very toxic for sea organisms. In particular, aromatic and polycyclic aromatic hydrocarbons are among the most toxic components of dissolved OP, which have carcinogenic properties and have a serious negative impact on the environment. These substances accumulate in the tissues of fish and represent a real threat to human health [11].

\section{Discussion of the Results}

The most powerful sources of anthropogenic TSM in the Kerch Strait waters are associated with dredging and the subsequent dumping of seized soil into specially designated dumping areas $[1,12,13]$.

During the dredging works that were carried out at Kerch Marine Trade Seaport in June 2000, YugNIRO specialists recorded the highest TSM concentration in the Kerch Strait within the entire monitoring history: it reached $210-220 \mathrm{mg} / \mathrm{l}$ on the surface and $240-260 \mathrm{mg} / \mathrm{l}$ at the bottom, which is tens of times higher than the surrounding background (Fig. 1a).

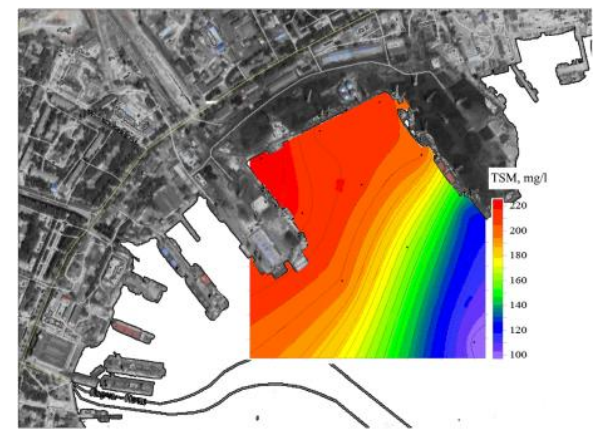

$a$

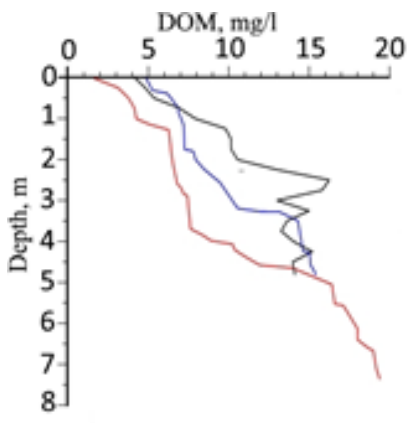

$b$

F i g. 1. Total suspended matter concentration on the surface within the water area of the Kerch commercial port during dredging in June, $2000(a)$ and suspended organic matter profiles $(z)$ nearby the port $(b)$

To compare, see the statistical indicators characteristic of the natural field of the TSM content in the Kerch Strait. The most frequently repeated concentrations of suspended matter in the Azov and Black Sea waters interacting in the strait are 2.8 and $0.8 \mathrm{mg} / \mathrm{l}$, respectively. The maximum (instrumentally recorded) TSM content in the considered water area $(70-80 \mathrm{mg} / \mathrm{l})$, which was caused by natural factors, was observed after storms. Under the conditions of a developed current in the strait narrowness, the maximum TSM content does not exceed 15-20 mg/l. 
In addition to Kerch Marine Trade Seaport, capacious dredging works in the studied water area were carried out in the Iron Ore Plant port and in the Fishing Port, as well as main Kerch-Enikalsky Canal and in the navigation canals approaching the ports. As a result, significant amounts of suspended matter entered the strait water column, which various solutes of anthropogenic origin were absorbed on. Some of them sank out to the bottom in the areas of dredging, the other part was spread by advective currents. Equally powerful saturation with suspended matter of water, apparently, accompanies the soil discharge withdrawn as a result of dredging works into the dumping areas.

Fig. 1b shows profiles reflecting the vertical structure of the DOM concentration field at the approach. It is seen that in these areas the content of this substance reached $18 \mathrm{mg} / \mathrm{l}$. The natural norm of DOM concentration in the Black Sea waters is $2 \mathrm{mg} / \mathrm{l}$ [14], and in the Azov Sea waters adjacent to the strait, according to the MHI data, is 1-3 mg/l. The bottom layer of water approaching the port of the navigable canal (red color profile) turned out to be the most polluted by this substance. The dissolved organic matter of anthropogenic nature enters the port area with the polluted waters of the Melek-Chesme and Bulganak rivers.

For the water area adjacent to the port, an increased background of the dissolved OP content (1.2-1.5 rel. units) is also characteristic. Their sources are connected with the oil terminal (which is located on Cape Belyi), the advection of polluted water from the Azov Sea and the operation of the fleet.

In the summer of 2013, dredging was carried out in the approach channel of the Fishing port. Echo survey, carried out within 1.5 months after the completion of the deepening works, did not reveal real results. The channel was filled with liquefied soil to the previous marks.

Modern bottom sediments in the Kerch Strait, according to the geological study of their physical properties [1], have their own characteristics. They are featured by extremely low compaction and abnormally high fluidity. This quality confirms the following empirical fact. In 1999, in the course of surveying hydrographic work on a shelf off the southwestern coast of the Kerch Strait, three miles northeast of Cape Takil, at a depth of 29-30 m, a local bottom uplift was detected. Against the background of the surrounding relief, it stood out with a distinct peak with a relative elevation of 1.4-1.6 m. The horizontal scale of this morphometric formation is about $70 \mathrm{~m}$. Details of the structure of the analyzed elevation on the zonal track of hydrographic survey, which passed through its middle part and was carried out in April 1999, are indicated by Line 1 in Fig. 2.

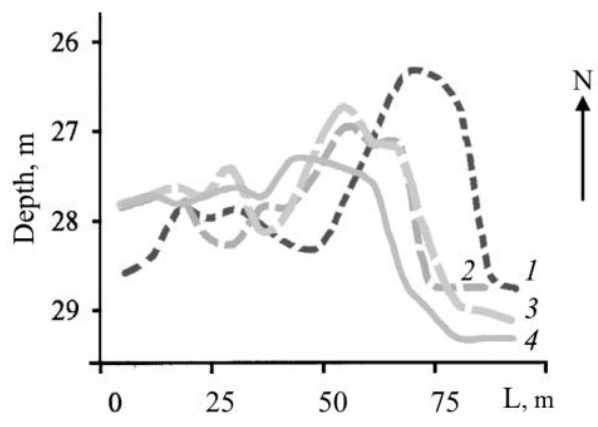

F i g. 2. Relief dynamics in the region of the local bottom elevation along the zonal sounding track in 1999: 1 - April, 2 - June, 3 - September, 4 - November 
According to this survey results, as well as an analysis of earlier information about the bottom topography of the surrounding sea area, it was suggested that the detected bottom elevation was an illegal landfill that could have appeared in 1998-1999.

During 1999, the zonal survey track through the middle of the morphometric formation under consideration was carried out three more times: in June, September and November (Fig. 2).

Analysis of the data obtained showed that the detected bottom elevation was quickly transformed. Its top blurred, shifting in the western direction, and almost disappeared by November. The western slope became flat and rose by $0.4-0.6 \mathrm{~m}$ as compared to the situation recorded in April. Over the 6-7 month time interval, the sea depth above the eastern slope of the elevation increased by $2 \mathrm{~m}$, and over the western slope decreased by $0.6 \mathrm{~m}$.

Unnaturally intensive processes of erosion and accumulation of bottom sediments in the considered bottom area indicate an anomalously low soil density in the elevation area being analyzed and its apparent artificial nature. With a high degree of probability, it can be argued that the detected local bottom elevation is the result of soil dumping, which was removed during dredging works. According to marine industry experts, similar cases for the Azov-Black Sea basin are not isolated. In order to save money, the removed soil is sometimes dumped near the dredging areas or on the way to the existing dumping zone.

There are currently 7 dumping zones in the Kerch Strait and in the pre-strait water areas of both seas, 6 of which are closed and one (dumping zone 7) located in the Black Sea pre-strait near Cape Takil is the current one (Fig. 3).

In the area of each of these dumping areas, YugNIRO employees carried out complex oceanological studies at different times and with varying degrees of detail in order to identify the influence of these zones on the quality of surrounding waters and the state of biological objects. The most succinct results were obtained for dumping areas 3 and 7 (Fig. 3).

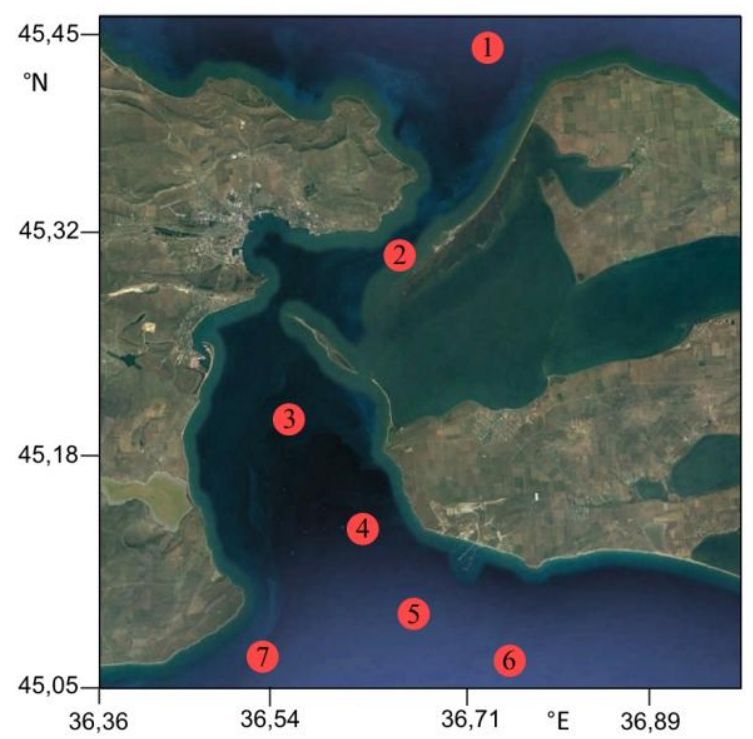

F i g. 3. Scheme of location of dumping zones (1-7) in the Kerch Strait water area 
Thus, the result of studies carried out in the 70-80-ies of the last century in areas of dumping zones operating at that time, can be summarized as follows. Dumps of the soil withdrawn as a result of dredging, which were organized in the Kerch Strait in the 1960s - 1980s of the last century, led to the formation of vast zones of mass suffocation, accompanied by hydrogen sulfide contamination of the bottom layer, the defeat of biocenoses, the mass death of fish and mussels and the loss of huge areas for feeding and spawning of fish.
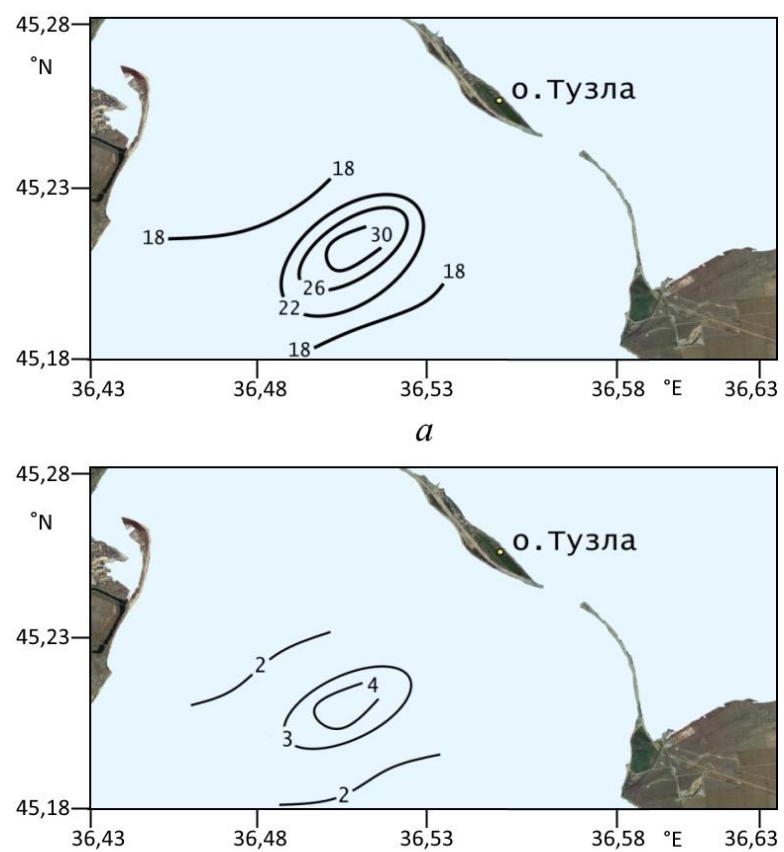

6

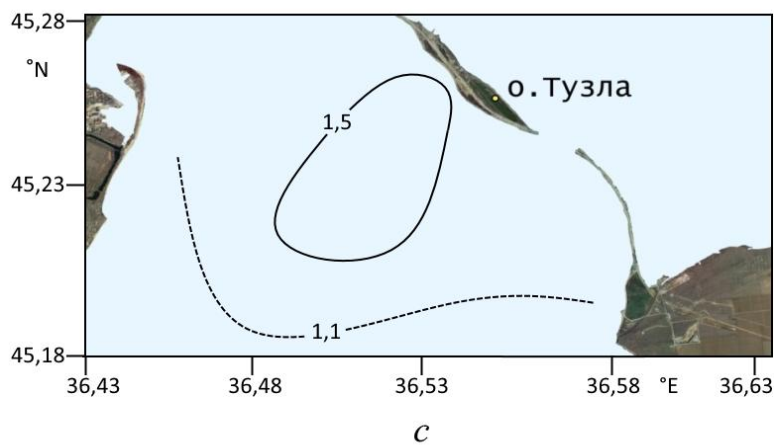

F i g. 4. Distribution of concentrations of total suspended matter, $\mathrm{mg} / \mathrm{l}(a)$, dissolved organic matter, $\mathrm{mg} / \mathrm{l}(b)$ and dissolved oil products, relative units $(c)$ in the bottom layer in the region of the closed dumping zone 3 in May, 2005

Fig. 4 shows the distribution of oceanological characteristics in May 2005 in the bottom layer in the area of the dumping zone 3, which was located to the south of the Tuzla Island (Fig. 3) and was closed in 1973. 
It can be seen that after 32 years after the soil-dumping ban on into this dumping zone, it clearly had a negative effect on the quality of the surrounding waters. In the dumping zone area, a local maximum of the TSM, DPM and dissolved OP concentration, which was 1.5-2 times higher than the natural norm in all considered environmental characteristics, was observed on the surrounding background.

In the area of the existing dumping zone (Fig. 3, dumping zone 7) in 2002 and 2008 , the concentration of the considered substances under consideration at the bottom was 2-3 times higher than their natural content (Fig. 5). The high concentration of pollutants confirms the opinion of the author of the work [15], according to which both closed and active dumping zones located in the Kerch Strait are significant sources of water pollution.
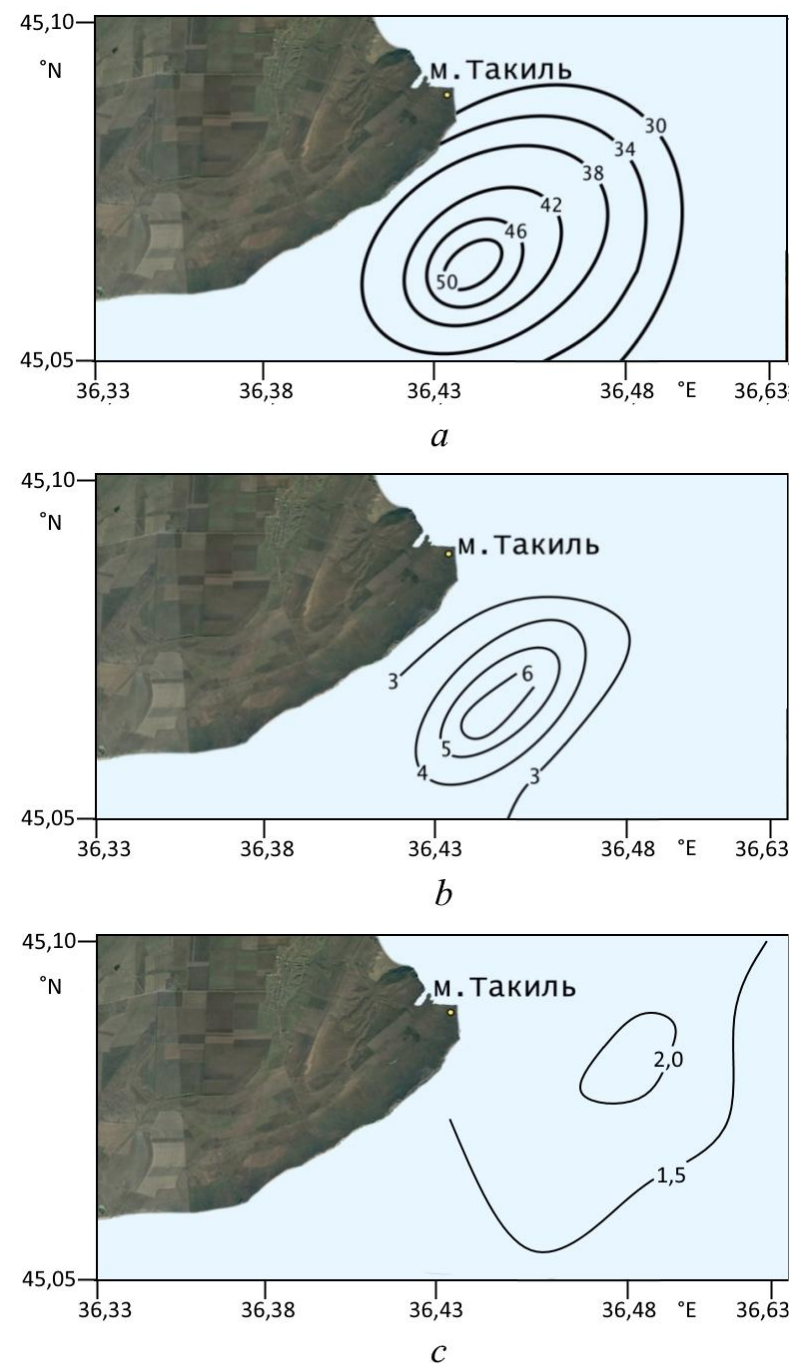

F i g. 5. Distribution in the bottom layer of total suspended matter $(a)$ and dissolved organic matter (b) concentrations, $\mathrm{mg} / \mathrm{l}$ in November 2002, and dissolved oil products content, relative units $(c)$ in the region of the active dumping zone in April, 2008 
The constant presence of excess TSM, DPM and dissolved OP content in the dumping zones is due to the low density of the upper soil layer in these areas. Therefore, ceteris paribus (wind, waves, current or human-induced physical impact on the water column caused by a moving vessel), the upsetting of the bottom layer of water is more intense here. Organics and oil products dissolved in water are sorbed by the suspension and settle to the bottom, forming local maxima of their own concentration above the dumping zones.

In recent years, the processes of sediment accumulation of navigable canals have intensified, there has been an active shallowing of Kamysh-Burun and Kerch bays, Kerch Marine Trade Seaport and Fishing port. In the composition of bottom sediments in the waters of these objects particles of relict sedimentary material were found. Their age is estimated at several millennia, and their depth of occurrence is several meters below the modern bottom level [1]. It is obvious that historical sedimentary material lying under the bottom of the strait could go into suspension in the water column only as a result of anthropogenic interference artificial destruction of the bottom by deepening works.

Therefore, dredging and dumping zones located in the Kerch Strait water area are not only sources of environmental hazard, they are also unfavorable in terms of navigation. Sedimentary material from the dredging sites and dumping zones are recorded in the Kerch Strait water area, ports and navigation canals.

\section{Conclusion}

The structural regularities of the total suspended matter (TSM) and dissolved organic matter (DOM) content fields and the dissolved oil products (OP) concentration in the dredging and dumping areas in the Kerch Strait and the adjacent regions were found out based on the oceanographic data of the series of expeditions of the Marine Hydrophysical Institute and the Southern Research Institute of Marine Fishery and Oceanography.

During the dredging works at Kerch Marine Trade Seaport, the maximum during the entire observation period TSM concentration was recorded. It was two orders of magnitude higher than the content of this substance in the Black and Azov Sea waters. The high content of suspended matter characteristic of the port and the surrounding water area contributes to the accumulation and deposition of anthropogenic DOM and dissolved OP.

It was confirmed that the soil removed during dredging has low compactness and abnormally high fluidity, which contributes to the intensive erosion of the dumping zones and the sediment accumulation of the surrounding water area.

It was revealed that the dumping zone closed in 1973, located south of the Tuzla Island remains a source of water pollution. Here, in the bottom layer, a local maximum of the TSM, DPM and dissolved OP concentration, clearly expressed on the surrounding background, was recorded. It was 1.5-2 times higher than the natural norm in all the considered characteristics of the medium.

In the area of the active dumping zone located at Cape Takil, the concentration of the pollutants analyzed 2-3 times exceeded their natural norm.

It is shown that dredging and dumping areas are not only sources of environmental hazards, they are also unfavorable for navigation, since they are significant sediment accumulation sources of ports and navigable canals. 


\section{REFERENCES}

1. Lomakin, P.D. and Spiridonova, E.O., 2010. Prirodnye $i$ Antropogennye Izmeneniya $v$ Polyakh Vazhneyshikh Abioticheskikh Elementov Ekologicheskogo Kompleksa Kerchenskogo Proliva v Techenie Dvukh Poslednikh Desyatiletiy [Natural and Anthropogenic Changes in the Fields of the Most Important Abiotic Elements of the Ecological Complex of the Kerch Strait over the Past Two Decades]. Sevastopol: ECOSI-Gidrofizika, 118 p. (in Russian).

2. Stronkhorst, J., Ariese, F., van Hattum, B., Postma, J.F., de Kluijver, M., Den Besten, P.J., Bergman, M.J.N., Daan, R., Murk, A.J. and Vethaak, A.D., 2003. Environmental Impact and Recovery at Two Dumping Sites for Dredged Material in the North Sea. Environmental Pollution, [e-journal] 124(1), pp. 17-31. https://doi.org/10.1016/S0269-7491(02)00430-X

3. Simonini, R., Ansaloni, I., Cavallini, F., Graziosi, F., Iotti, M., Massamba N'Siala, G., Mauri, M., Montanari, G., Preti, M and Prevedelli, D., 2005. Effects of Long-Term Dumping of Harbor-Dredged Material on Macrozoobenthos at Four Disposal Sites along the EmiliaRomagna Coast (Northern Adriatic Sea, Italy). Marine Pollution Bulletin, [e-journal] 50(12), pp. 1595-1605. https://doi.org/10.1016/j.marpolbul.2005.06.031

4. Van der Wal, D., Forster, R.M., Rossi, F., Hummel, H., Ysebaert, T., Roose, F. and Herman, P.M.J., 2011. Ecological Evaluation of an Experimental Beneficial Use Scheme for Dredged Sediment Disposal in Shallow Tidal Waters. Marine Pollution Bulletin, [e-journal] 62(1), pp. 99-108. https://doi.org/10.1016/j.marpolbul.2010.09.005

5. Donázar-Aramendía, I., Sánchez-Moyano, J.E., García-Asencio, I., Miró, J.M., Megina, C. and García-Gómez, J.C., 2018. Impact of Dredged-Material Disposal on Soft-Bottom Communities in a Recurrent Marine Dumping Area near to Guadalquivir Estuary, Spain. Marine Environmental Research, [e-journal] 139, pp. 64-78. https://doi.org/10.1016/j.marenvres.2018.05.010

6. Chepyzhenko, A.A. and Chepyzhenko, A.I., 2017. Methods and Device for in Situ Total Suspended Matter (TSM) Monitoring in Natural Waters' Environment. In: SPIE, 2017. Proceedings Volume 10466, 23rd International Symposium on Atmospheric and Ocean Optics: Atmospheric Physics, 104663G. http://dx.doi.org/10.1117/12.2287127

7. Chepyzhenko, A.I. and Chepyzhenko, A.A., 2017. Methods and Device for in Situ Dissolved Organic Matter (DOM) Monitoring in Natural Waters' Environment. In: SPIE, 2017. Proceedings Volume 10466, 23rd International Symposium on Atmospheric and Ocean Optics: Atmospheric Physic; 104663S. http://dx.doi.org/10.1117/12.2287797

8. Boss, E., Pegau, W.S., Zaneveld, J.R.V. and Barnard, A.H., 2001. Spatial and Temporal Variability of Absorption by Dissolved Material at a Continental Shelf. Journal of Geophysical Research: Oceans, [e-journal] 106(C5), pp. 9499-9507. doi:10.1029/2000JC900008

9. Tedetti, M., Longhitano, R., Garcia, N., Guigue, C., Ferretto, N. and Goutx, M., 2012. Fluorescence Properties of Dissolved Organic Matter in Coastal Mediterranean Waters Influenced by a Municipal Sewage Effluent (Bay of Marseilles, France). Environmental Chemistry, [e-journal] 9(5), pp. 438-449. https://doi.org/10.1071/EN12081

10. Holdway, D., Radlinski, A., Exon, N., Auzende, J-M. and Van de Beuque, S., 2000. Continuous Multi-Spectral Fluorescence and Absorption Spectroscopy for Petroleum Hydrocarbon Detection in Near-Surface Ocean Waters: ZoNeCo5 Survey, Fairway Basin Area, Lord Howe Rise. Canberra: Australian Geological Survey Organization, 57 p. Available at: https://d28rz98at9flks.cloudfront.net/34232/Rec2000_035.pdf [Accessed: 17 November 2018].

11. National Research Council of the National Academies, 2003. Oil in the Sea III: Inputs, Fates, and Effects. Washington, D.C.: The National Academies Press, 265 p. Available at: https://www.nap.edu/read/10388/chapter/1 [Accessed: 15 November 2018].

12. Petrenko, O.A., Sebakh, L.K. and Fashchuk, D.Ya., 2002. Some Environmental Consequences of Soil Dumping in the Black Sea as a Result of Dredging Operations in the Kerch Strait. Water Resources, [e-journal] 29(5), pp. 573-586. https://doi.org/10.1023/A:1020338201171 
13. Lomakin, P.D., Chepyzhenko, A.I. and Chepyzhenko, A.A., 2017. The Total Suspended Matter Concentration Field in the Kerch Strait Based on Optical Observations. Physical Oceanography, [e-journal] (6), pp. 58-69. doi:10.22449/1573-160X-2017-6-58-69

14. Khaylov, K.M., 1971. Ekologicheskiy Metabolizm v More [Ecological Metabolism in the Seas]. Kiev: Naukova Dumka, 252 p. (in Russian).

15. Bryantsev, V.A., 2005. Vozmozhnye Ekologicheskie Posledstviya Sooruzheniya Tuzlinskoy Damby (Kerchenskiy Proliv) [Possible Ecological Consequences of the Tuzla Damb Construction (Kerch Strait)]. Morskoy Ekologicheskiy Zhurnal = Marine Ekological Journal, 4(1), pp. 47-50. Available at: https://repository.marine-research.org/handle/299011/784 [Accessed: 10 April 2019] (in Russian).

About the author:

Pavel D. Lomakin - Senior Research Associate, Marine Hydrophysical Institute of RAS (2 Kapitanskaya St., Sevastopol, Russian Federation, 299011), Ph.D. (Geogr.), Professor, ResearcherID: V-7761-2017, p_lomakin@mail.ru

The author has read and approved the final manuscript.

The author declares that he has no conflict of interest. 